\title{
Effects of Sowing Date on the Growth, Yield and Honey Bee Foraging Intensity of Buck Wheat (Fagopyrum esculentum) at Bako Agricultural Research Center
}

\author{
Tusa Gemechu*, Amsalu Arega \\ Email address: \\ tusagemechu99@gmail.com (T. Gemechu) \\ ${ }^{*}$ Corresponding author
}

Bako Agricultural Research Center, Oromia Agricultural Research Institute, Bako, West Shoa, Oromia, Ethiopia

\section{To cite this article:}

Tusa Gemechu, Amsalu Arega. Effects of Sowing Date on the Growth, Yield and Honey Bee Foraging Intensity of Buck Wheat (Fagopyrum esculentum) at Bako Agricultural Research Center. Ecology and Evolutionary Biology. Vol. 3, No. 1, 2018, pp. 1-4.

doi: 10.11648/j.eeb.20180301.11

Received: July 28, 2017; Accepted: December 21, 2017; Published: January 31, 2018

\begin{abstract}
The flexibility and wide adaptation of buck wheat recently led it to be grown on different agro ecology, even though it is not native to our country. A field experiment was conducted to study the effects of sowing date on growth, yield and honey bee foraging intensity of buckwheat at Bako Agriculture Research Center. There were 5 treatments with the first treatment sown on July, 15 having 10 days different between each treatments with three replications laid out in Randomized Complete Block Design (RCBD). The experimental result showed that there was significance difference White seeded Variety (V2) of buckwheat having 37 days stay with flowering which is planted in the Mid July and early August with the mean value of about 31 days with extended flowering period and proceeds prolifically for about a month before gradually tapering off as the plant matures. From the result above buckwheat was mature in 11 weeks. The later buckwheat is planted, the faster it will mature. Therefore, speed of maturity depends on the planting date. Grain yield of buckwheat under different sowing date were highly significant $(\mathrm{p} \leq 0.05)$ highest grain yield for both Varieties planted in mid July and late July with the lowest grain yield observed for both Varieties planted in the late August with the mean value of $14.40 \mathrm{ku} / \mathrm{ha}$. The result clearly indicates that foraging intensity of honey bees at different flowering stage of the buck wheat has been significantly different at first week flowering and second week of flowering stage with mean value of 36 and $31 \mathrm{bees} / \mathrm{m}^{2} / 10 \mathrm{~min}$. The intensive visitation of honey bees with the mean value of $22 \mathrm{bees} / \mathrm{m}^{2} / 10 \mathrm{~min}$ and $13 \mathrm{bees} / \mathrm{m}^{2} / 10 \mathrm{~min}$ at early in the morning (08:30-08:40 am) and (04:3004:40 am) has been observed respectively.
\end{abstract}

Keywords: Buck Wheat, Foraging Intensity, Honey Bee, Sowing Date, Yield

\section{Introduction}

The flexibility and wide adaptation of buck wheat recently led it to be grown on different agro ecology, even though it is not native to our country. The seeds germinate and emerge rapidly when planted in warm soil, typically in three to four days. Flowering begins about three weeks after planting, and proceeds prolifically for a few weeks, before gradually tapering off as the plant matures. The prolific flowers on buckwheat have made the crop a good nectar source for honey bee keepers. Buckwheat flowers are very fragrant and are attractive to bees that use them to produce a special, strongly flavored, dark memorable honey. Plant height and speed of maturity depend on planting date. If planted early in the summer, and given good fertility, plants usually may take 10 to 12 weeks to mature [1]. The later buckwheat is planted, the faster it will mature. The reason to plant buckwheat relatively late is to push flowering into a period when nights are starting to cool down, which will normally be the case in late August or early September. In buckwheat, seed set is globally very low, around $15-30 \%$ which is the major constraint to buckwheat production worldwide [2].

Buckwheat is primarily a human food crop, used in similar fashion to cereal grains such as wheat or oats. It has also been used widely as a cover crop to smother weeds and improve the soil. The crop seems to improve soil tilt, and is 
reported to make phosphorous more available as a soil nutrient, possible through root-associated mycorrhizae. Common buckwheat is one of the best source of high quality, easily digestible protein, having a balanced amino acid composition [3] and a good source of minerals. It is cholesterol free and perfectly fits our modern low calorie, high nutrition diets [4]. In alternative medicine, it is used for balancing the sugar and cholesterol level in the blood [5].

Buckwheat is cross pollinated and an entomophilous plant; honeybees are the major pollinators. The cultivation of buckwheat along with beekeeping may produce 50 to $100 \mathrm{~kg}$ of honey per hectare, due to its extended flowering period for more than 30 days [6]. Many factors, such as the floral physiology and morphology, pollinator characteristics, as well as effects of weather influence the success of pollination. Buckwheat pollen is not windblown; therefore insects are necessary for the transfer of pollen. Buckwheat flowers in the first sunshine and during which time it is highly attractive to bees [7] and most of the pollination activities occur. It is said that a single visit of buckwheat flowers by a bee increases plant productivity by $25-30 \%$ [8] three to four insect visits are enough to pollinate one blossom of buckwheat while bee visiting more than 5 times the productivity of plant decreases [9]. Although some information on the adaptation and uses of buckwheat from honey bee side of buckwheat has appeared over the past 10 years, a great deal of buckwheat time of plantation, honey bees foraging intensity and other effort is still required. Therefore, the objective of this study was to see the effects of planting date on the growth, yield and honey bee foraging intensity of buckwheat.

\section{Materials and Methods}

A field experiment was conducted to study the effects of sowing date on growth, yield and honey bee foraging intensity of buckwheat at Bako Agriculture Research Center. There were 5 treatments with the first treatment sown on July, 15 having 10 days different between each treatments with three replications laid out in Randomized Complete Block Design (RCBD). Land preparation was done by conventional tillage and harrowing with plot size of $3 \mathrm{~m} \times 3 \mathrm{~m}$ within this area, $1 \times 1 \mathrm{~m}^{2}$ was taken as experimental unit for honey bee foraging intensity data recording. $1 \mathrm{~m}$ between reps and plots, $30 \mathrm{~cm}$ between rows and seed rate of $50 \mathrm{~kg} / \mathrm{ha}$ and $46 \mathrm{~kg} / \mathrm{ha}$ Fertilizer rate were used. Plants were harvested manually with the help of sickle when it is expected to be matured. Plants were allowed to dry for easy threshing. Threshing was done by beating with sticks.

The data obtained from experimental plots were recorded and analyzed by using One-way Analysis of Variance (ANOVA) procedure described by [10]. When the F-test indicated statistical significance at the $(P \leq 0.05)$ level, the Duncan's Multiple Range Test was used to compare the difference of the means.

\section{Results and Discussion}

Table 1. Effects of sowing date on the agronomic and yield parameters of buck wheat varieties.

\begin{tabular}{|c|c|c|c|c|c|c|c|c|}
\hline SD & $\mathbf{V}$ & DE & DH & DF & DF-to DEF & DEF & DM & $\mathrm{Y}$ in $\mathrm{Q} / \mathrm{ha}$ \\
\hline \multirow{2}{*}{ July, 15} & 1 & $4.17^{\mathrm{a}}$ & $20.67^{b c}$ & $27.17^{\text {abcd }}$ & $30^{\text {cd }}$ & $57.17^{\mathrm{bc}}$ & $79.0^{\mathrm{bc}}$ & $19.54^{\mathrm{a}}$ \\
\hline & 2 & $4.67^{\mathrm{a}}$ & $21.17^{\mathrm{ab}}$ & $27.83^{\mathrm{abc}}$ & $37.67^{\mathrm{a}}$ & $65.50^{\mathrm{a}}$ & $88.0^{\mathrm{a}}$ & $21.61^{\mathrm{a}}$ \\
\hline \multirow{2}{*}{ July, 25} & 1 & $4.83^{\mathrm{a}}$ & $24.00^{\mathrm{a}}$ & $28.83^{\mathrm{a}}$ & $26.5^{\mathrm{d}}$ & $55.33^{\mathrm{bc}}$ & $77.0^{\mathrm{bc}}$ & $19.35^{\mathrm{a}}$ \\
\hline & 2 & $5.17^{\mathrm{a}}$ & $24.00^{\mathrm{a}}$ & $28.33^{\mathrm{ab}}$ & $35.50^{\mathrm{ab}}$ & $63.83^{\mathrm{a}}$ & $86.33^{\mathrm{a}}$ & $21.72^{\mathrm{a}}$ \\
\hline \multirow{2}{*}{ Aug, 05} & 1 & $4.33^{\mathrm{a}}$ & $21.83^{\mathrm{ab}}$ & $26.83^{\text {bcd }}$ & $28.83^{\mathrm{d}}$ & $55.67^{\mathrm{bc}}$ & $73.0^{\text {cde }}$ & $11.92^{\mathrm{bc}}$ \\
\hline & 2 & $4.83^{\mathrm{a}}$ & $22.33^{\mathrm{ab}}$ & $26.83^{\mathrm{bcd}}$ & $37.17^{\mathrm{a}}$ & $64.00^{\mathrm{a}}$ & $81.0^{\mathrm{ab}}$ & $17.79^{\mathrm{ab}}$ \\
\hline Aug, 15 & 1 & $5.67^{\mathrm{a}}$ & $17.33^{\mathrm{d}}$ & $26.17^{\text {cd }}$ & $26.83^{d}$ & $53.00^{\mathrm{c}}$ & $69.67^{\mathrm{de}}$ & $8.38^{\mathrm{cd}}$ \\
\hline \multirow{2}{*}{ Aug, 25} & 1 & $4.67^{\mathrm{a}}$ & $20.33^{b c}$ & $26.00^{\mathrm{cd}}$ & $26.83^{d}$ & $52.83^{c}$ & $65.8^{\mathrm{e}}$ & $4.78^{d}$ \\
\hline & 2 & $5.17^{\mathrm{a}}$ & $20.83^{b c}$ & $26.17^{\mathrm{cd}}$ & $31.50^{\text {bcd }}$ & $57.67^{\mathrm{b}}$ & $69.17^{\text {ed }}$ & $9.06^{\mathrm{cd}}$ \\
\hline Mean & & 4.88 & 21.05 & 26.95 & 31.50 & 58.45 & 76.4 & 14.40 \\
\hline SEM & & 0.13 & 0.36 & 0.21 & 0.64 & 0.66 & 1.3 & 1.52 \\
\hline $\mathrm{CV}$ & & 19.56 & 8.34 & 3.92 & 9.23 & 4.43 & 5.7 & 35.19 \\
\hline
\end{tabular}

Where, $\mathrm{SD}=$ Sowing Date, $\mathrm{V}=$ Varieties, DE=Days of Emergency, DH=Days of Heading, DF=Days of Flowering, DEF=Days of End flowering, DM=Days of Maturity, $\mathrm{Y}=$ Yield.

No significance difference has been observed on the days of emergency for both buckwheat varieties planted at different dates. But, there were significance difference on the days of heading, longer heading dates for both buckwheat varieties planted in the late July (24 Days) and shorter heading dates Black seeded (V1) buckwheat varieties planted in mid- August (17 Days), with the mean heading date of about three weeks after planting.

Both buckwheat varieties planted in the late July shows significantly longer days (28 days) of flowering with the shorter days white seeded (V2) buckwheat planted in mid
August (25 days) after planting. The results for days of flowering and maturity was found in the range reported by [11] that days to $50 \%$ flowering was $26-45$ and days to maturity were 67-98.

There was significance difference on stay with flowering for long period of time having longer (37 days) of buckwheat white seeded (V2) planted in the Mid July and early August, with the mean value of 31 days having extended flowering period and proceeds prolifically for about a month before gradually tapering off as the plant matures. 


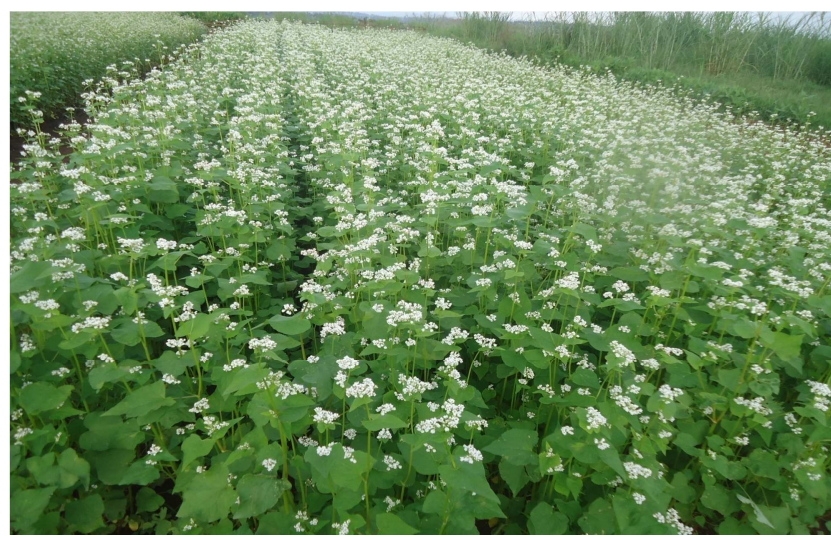

Figure 1. Buckwheat in full bloom at Bako Agriculture Research Center.

From the result above buck wheat was mature in 11 weeks. This was similar with the other finding which states that if planted early in the summer, and given good fertility, plants usually may take 11 to 12 weeks to mature [11]. If planted in the latter part of July, buckwheat will mature in about 9 to 10 weeks. The later buckwheat is planted, the faster it will mature. Therefore, speed of maturity depends on the planting date. Grain yield of buck wheat under different sowing date were highly significant $(\mathrm{p} \leq 0.05)$ highest grain yield for both Varieties planted in mid July and late July with the lowest grain yield observed for both Varieties planted in the late August with the mean value of $14.40 \mathrm{Q} / \mathrm{ha}$. This result has been found below the average of world grain yield which states that, buckwheat crop removes $47 \mathrm{~kg}$ nitrogen, $22 \mathrm{~kg}$ phosphorus and $40 \mathrm{~kg}$ potassium for each hectare seeded and gives a yield of $1600 \mathrm{~kg} / \mathrm{ha}$ in Manitoba, Canada [12]. Possibly this recorded variation results from different rating systems or to the large variation that is available in the different sowing date of Buckwheat, which is caused by the large variation in altitude and agro ecological conditions under which they have developed. [2] found that the yield of common buckwheat increased with high soil moisture although seed set remained essentially the same.

Table 2. Effects of different sowing date on honey bee foraging intensity at different flowering stages of buck wheat varieties.

\begin{tabular}{llll}
\hline Sowing Date & Varieties & Foraging Intensity of Bees at First Week of Flowering & Foraging Intensity of Bees at Second Week After Flowering \\
\hline \multirow{2}{*}{ July, 15} & 1 & $38.00^{\mathrm{abc}}$ & $17.50^{\mathrm{de}}$ \\
& 2 & $48.33^{\mathrm{a}}$ & $58.17^{\mathrm{a}}$ \\
July, 25 & 1 & $34.00^{\mathrm{bc}}$ & $30.17^{\mathrm{bcd}}$ \\
& 2 & $38.83^{\mathrm{abc}}$ & $40.33^{\mathrm{b}}$ \\
Aug, 05 & 1 & $34.33^{\mathrm{bc}}$ & $33.17^{\mathrm{bc}}$ \\
& 2 & $42.33^{\mathrm{ab}}$ & $37.67^{\mathrm{bc}}$ \\
Aug, 15 & 1 & $35.67^{\mathrm{bc}}$ & $14.00^{\mathrm{e}}$ \\
& 2 & $30.17^{\mathrm{bc}}$ & $29.50^{\mathrm{bcd}}$ \\
Aug, 25 & 1 & $28.50^{\mathrm{c}}$ & $27.33^{\mathrm{bcd}}$ \\
Mean & 2 & $30.00^{\mathrm{c}}$ & $27.00^{\mathrm{cd}}$ \\
SEM & & 36.02 & 31.48 \\
CV & 2.03 & 3.25 \\
\hline
\end{tabular}

There were high significance differences in the flowering intensity of honey bees highest number of bees visit has been observed for white seeded (V2) \& black seeded (V1) varieties of buck wheat both planted in mid July (48.33 bees $\left./ \mathrm{m}^{2} / 10 \mathrm{~min}\right)$ and $\left(38\right.$ bees $\left./ \mathrm{m}^{2} / 10 \mathrm{~min}\right)$ respectively with the mean value of about 36 visitors of bees $/ \mathrm{m}^{2} / 10 \mathrm{~min}$ in the first week of flowering. However, in the second round of flowering intensity of honey bees V2 planted in the mid July $58 \mathrm{bees} / \mathrm{m}^{2} / 10 \mathrm{~min}$ ) followed by the same variety planted in the late July about $40 \mathrm{bees} / \mathrm{m}^{2} / 10 \mathrm{~min}$ with lower bee visit V1 planted in the mid August 14 bees $/ \mathrm{m}^{2} / 10$ min having the mean value of 31.48 bees $/ \mathrm{m}^{2} / 10 \mathrm{~min}$.

Table 3. Effects of sowing date on honey bee Intensity to visit Buck wheat forage at different time of the day.

\begin{tabular}{|c|c|c|c|c|c|}
\hline \multirow{2}{*}{ Sowing Date } & \multirow{2}{*}{ Variety } & \multicolumn{4}{|c|}{ Time of Honey Bee Visit Buck Wheat } \\
\hline & & 02:30-02:40 & 04:30-04:40 & 07:30-07:40 & $\begin{array}{c}09: 30-09: 40 \\
\end{array}$ \\
\hline \multirow{2}{*}{ July, 15} & 1 & $13.67^{\mathrm{d}}$ & $6.67^{\mathrm{c}}$ & $1.67^{\mathrm{a}}$ & $0.17^{\mathrm{b}}$ \\
\hline & 2 & $29.17^{\mathrm{a}}$ & $13.67^{\mathrm{ab}}$ & $0.83^{\mathrm{a}}$ & $0.00^{\mathrm{b}}$ \\
\hline \multirow{2}{*}{ July, 25} & 1 & $15.33^{\text {cd }}$ & $11.83^{\mathrm{ab}}$ & $1.00^{\mathrm{a}}$ & $0.33^{\mathrm{ab}}$ \\
\hline & 2 & $27.00^{\mathrm{ab}}$ & $14.67^{\mathrm{ab}}$ & $1.00^{\mathrm{a}}$ & $0.00^{\mathrm{b}}$ \\
\hline \multirow{2}{*}{ Aug, 05} & 1 & $24.33^{\mathrm{ab}}$ & $14.33^{\mathrm{ab}}$ & $1.17^{\mathrm{a}}$ & $0.00^{\mathrm{b}}$ \\
\hline & 2 & $28.17^{\mathrm{ab}}$ & $14.00^{\mathrm{ab}}$ & $1.50^{\mathrm{a}}$ & $0.00^{\mathrm{b}}$ \\
\hline \multirow{2}{*}{ Aug, 15} & 1 & $16.00^{\text {cd }}$ & $10.33^{\mathrm{bc}}$ & $1.00^{\mathrm{a}}$ & $0.00^{\mathrm{b}}$ \\
\hline & 2 & $22.83^{\mathrm{abc}}$ & $14.33^{\mathrm{ab}}$ & $0.83^{\mathrm{a}}$ & $0.33^{\mathrm{ab}}$ \\
\hline \multirow{2}{*}{ Aug, 25} & 1 & $21.50^{\mathrm{abcd}}$ & $16.33^{\mathrm{a}}$ & $1.50^{\mathrm{a}}$ & $0.00^{\mathrm{b}}$ \\
\hline & 2 & $20.00^{\text {bcd }}$ & $14.67^{\mathrm{ab}}$ & $1.33^{\mathrm{a}}$ & $0.83^{\mathrm{a}}$ \\
\hline Mean & & 21.8 & 13.08 & 1.18 & 0.17 \\
\hline SEM & & 1.16 & 0.68 & 0.09 & 0.07 \\
\hline $\mathrm{CV}$ & & 19.6 & 20.5 & 38.4 & 19.4 \\
\hline
\end{tabular}

From the result significance difference for flowering intensity of honey bees has been observed higher bee visiting during time 08:30-08:40 am buck wheat V2 planted in the mid July (29.17 bees $\left./ \mathrm{m}^{2} / 10 \mathrm{~min}\right)$. But, lower for V1 planted in 
the same date $\left(13.67 \mathrm{bees} / \mathrm{m}^{2} / 10 \mathrm{~min}\right)$

Generally honey bee foraging intensity, varies with time of the day. The intensive visitation of honey bees with the mean value of about 22 bees $/ \mathrm{m}^{2} / 10 \mathrm{~min}$ and 13 bees $/ \mathrm{m}^{2} / 10 \mathrm{~min}$ at early in the morning (08:30-08:40 am) and (04:30-04:40 am) has been recorded respectively. The result clearly indicate that length of the plant staying with flowering, grain yield, honey bee intensity at different flowering stage and time of bees visit at different time of the day of the study plant is affected by sowing dates. Flowers of cross-pollinating species of buckwheat are attractive to insects because of the nectar secreted by the glands at the base of the ovary. Bees and other insects contribute to the distribution of pollen. The glands secrete nectar only in the morning and early afternoon and therefore if honey bees are introduced to increase seed set they must be forced to work the buckwheat [10] (Campbell and Clayton G. 1997).

\section{Conclusion and Recommendations}

Buck wheat is one of the important honey bee forage. The seeds of buck wheat germinate and emerged rapidly 4-5 Days after planting. Flowering begins about 27 Days after planting and proceeds prolifically for about one month (31.5 Days) before gradually tapering off as the plant matures 10-11 Weeks after planting. The obtained average grain yield was about $14.4 \mathrm{~kg} / \mathrm{ha}$, Even though the seed set is the major constraint to buck wheat production worldwide.

Early flowering stage of buck wheat was intensively visited by honey bees than that of late flowering stage. As true for most of honey forages buck wheat was mostly visited by honey bees the time from $08: 30$ to $10: 40$ am than afternoon the time from 01:30 to 03:40 pm. Length of plant staying with flowering, grain yield, and honey bee foraging intensity at different flowering stage and time of bees visit at different time of the day of the study plant is affected by sowing dates. Therefore, planting buck wheat in the mid July to Late July is appropriate time for both honey bee intensively use and grain yield, with the seeding rate of $50 \mathrm{~kg} / \mathrm{ha}$ and fertilizer rate of about $46 \mathrm{~kg} / \mathrm{ha}$ for Bako and similar agro ecologies.

\section{References}

[1] Agriculture Canada. (1978). Growing buckwheat. Ottawa Canada: Canadian Department of Agriculture.
[2] Gubbels, G. H. 1978. Yield, seed weight, hull percentage and testa colour of buckwheatat two soil moisture regimes. Can. J. Plant Sci. 58:881-883.

[3] Eggum, B. O., Kreft, I. \& Javornik, B. (1981) Chemical composition and protein quality of buckwheat (Fagopyrum esculentum Moench). Qual. Plant Foods Hum. Nutr. 30: 175179 .

[4] Francischi, M. L., J. M. Salfado and R. F. Leitao. 1994. Chemical, nutritional and technological characteristics of buckwheat and prolamine buckwheat flours in comparison of wheat flour. Plant Foods and Human Nutrition 46: 323-329.

[5] Jiang Y, et al. (1995) BTS1 encodes a geranylgeranyl diphosphate synthase in Saccharomyces cerevisiae. J Biol Chem 270 (37):21793-9.

[6] Marshall, H. G. and Y. Pomeranz. 1982. Buckwheat: Description, breeding, production and, utilization. Pp. 157-210 in Advances in Cereal Science and Technology. Vol. 5. (Y. Pomeranz, ed.). American Associationof Cereal Chemists Incorporated, St. Paul, Minnesota.

[7] Phillips, E. F. and G. S. Demuth. 1922. Beekeeping in the buckwheat region. U.S. Department of Agricultural Farmers' Bulletin 1216: 26. Rajbhandari, B. P. 2010. Buckwheat in the land of Everest. Himalayan College of Agricultural Sciences and Technology (HICAST), Kathmandu, Nepal. 132p.

[8] Grigorenko, V. 1979. Okratnosti posešèenija pèelami greèichi. Pèelovodstvo 10:18-19. Jiang, H. M. J., P. K. Whelton, J. P. Mo, J. Y. Chen, M. C. Quian, P. S. Mo and G. Q. He. 1995. Oats and buckwheat intakes and cardiovascular disease risk factors in an ethnic minority in China. American Journal of Clinical Nutrition 61: 366-372.

[9] Bjorkman, T. 2002. Guide to buckwheat production in the Northeast. New York State Agriculture and Extension Service, Cornell University, Geneva. Available on:http://www.nysaes.cornell. edu/ hort/ faculty/bjorkman/buck/guide/index.html (Retrievedon 10/10/2011).

[10] Gomez, K. A. and A. A. Gomez. 1984. Statistical procedures for agricultural research. 2nd ed. John Wiley and Sons, Inc. New York, USA. 680 p.

[11] Baniya, B. K., D. M. S. Dongol, and N. R. Dhungel. 1995. Further characterization and evaluation of Nepalese buckwheat (Fagopyrum spp.) landraces. Pp. 295-304 in Current.

[12] Campbell, C. G. and G. H. Gubbels. 1978. Growing Buckwheat, Agriculture Canada Publication 1468. Agriculture Canada, Ottawa. 